\title{
Toxicity of dipterex: a field study
}

\author{
XIAOHAN HU,* YAOPING LU, SHOUZHEN XUE, YOUXIN LING, AND \\ XUEQI GU
}

From the Department of Occupational Health, School of Public Health, Shanghai Medical University, Shanghai, 200032, Peoples Republic of China

ABSTRACT This study summarises historical surveillance data collected from 1977 to 1982 and the $\overrightarrow{\vec{\omega}}$ results of a field study conducted thereafter (1983-4) in a dipterex packing workshop. The findings ${ }^{\circ}$ suggest that both airborne dipterex and dermal contamination contribute to the inhibition of blood $\frac{\mathbb{\Phi}}{3}$ cholinisterase (ChE) and that cases of poisoning in hot seasons can be attributed mainly to dermali absorption. At a level of $0.5 \mathrm{mg} / \mathrm{m}^{3}$, dipterex is shown to lead to a mild but appreciable inhibition of $\mathrm{ChE}$ activity. The results also indicate that blood $\mathrm{ChE}$ monitoring was sensitive both for long $\mathrm{A}$ term and short term exposed workers. As a result, the recommendation that the maximum allow- $\vec{A}$ able concentration for airborne exposure to dipterex be revised to $0.5 \mathrm{mg} / \mathrm{m}^{3}$, can be regarded at 9 providing only for relative safety.

Dipterex (trichlorifon), one of the common organophosphorous insecticides, has been widely used for about 30 years. In the past decade field studies have been directed at exploring any chronic effects and verifying the present maximum allowable concentration (MAC). ${ }^{1-4}$ Previous work performed by this group suggested that chronic toxic effects on worker's health exist below the present MAC $\left(1 \mathrm{mg} / \mathrm{m}^{3}\right)$, and therefore a lowering to $0.5 \mathrm{mg} / \mathrm{m}^{3}$ was recommended. ${ }^{4}$ Since such a recommendation needs support from studies in which workers experience different exposure concentrations, we conducted the present study in the dipterex packing workshop, Shanghai pesticide factory, in which average air concentrations historically were around the MAC. This plant offered a suitable site for further study of the recommended revision in the value for the MAC as well as study of the toxicity of dipterex at low exposure concentrations.

\section{Subjects}

The packing process in the workshop includes five steps: (1) bottle setting, (2) bottle filling, (3) boxing, (4) box removal, and (5) final packing for shipment. At each of the first three processes there is one worker whereas for the latter two processes there are two and

\section{Accepted 23 September 1985}

*Current address: Department of Environmental and Occupational Health Sciences, School of Public Health, UCLA, Los Angeles, CA 90024, USA. three workers, respectively. There is an additional $\vec{\varphi}$ worker for each shift who monitors the daily transfer $\infty$ of a certain proportion of dipterex to a nearby dichlorvos production process. One final worker is employed in a connected room labelling the bottles before their being sent to step 1. Workers in steps one to four and for dipterex transfer were divided into $\frac{\circ}{\square}$ three work shifts and rotated jobs daily in the se- $\cong$ quence of the working process. Job five and the label- $\overrightarrow{\overrightarrow{0}}$ ler worked only one shift. Beginning in 1984, job 3 rotation was greatly reduced and included rotation only between jobs one and three and between jobs two and four.

Shift workers were studied for five consecutive $\frac{\Phi}{3}$ three month seasons. For most, the recent pattern has been a cycle of employment in dipterex packing for only three months. This period has been separated by 8 three to six months of employment in other work in the nearby community before being re-employed in 0 packing dipterex. Four of the workers were per- $D$ manently employed throughout the study period. With intervals of three to six months between employment periods, workers' blood cholinesterase (ChE) $ᄋ$ activity returns to normal values well before re- N employment. $^{34}$ Therefore, it was considered that tests on each subject employed on a three month in- $\sigma$ termittent cycle could be treated as an independent observation even though several subjects were re- $\frac{-}{\Phi}$ employed.

Each seasonal work group has 22 workers. Al- though an effort was made to obtain blood samples from workers both before the three month season as 
well as at the end of the season, we failed to follow up a few workers when they were unwilling to be sampled. The last season studied followed a two month irregular production and two month shut down so that both temporary and permanent workers were combined for this survey lasting only two months.

Before this study period high market demand had resulted in a different employment pattern. For example, most workers had worked without three month intermissions for the two years from 1977 to 1979. These continuously employed workers were monitored regularly every three months during those years.

\section{Methods}

The study took advantage of both the summary of historical surveillance data collected in the period from 1977 to 1982 as well as the exposures collected for the study period $1983-4$.

The routine surveillance methods used included:

(1) conducting 20 minute environmental air sampling at different working sites to estimate the average air concentration; and

(2) collecting blood samples to measure blood $\mathrm{ChE}$ activity both before and after the three month employment cycle.

In addition to the routine surveillance, further work was undertaken for this study:

(1) measuring dermal contamination using a skin weighted measurement (see appendix);

(2) recording actual hours at each work station for estimating eight hours exposure as a time weighted average air concentration; and

(3) administering EEG examinations to look for toxic effects on the nervous system from chronic dipterex exposure.

Environmental samples were analysed for dipterex by the mercury thiocyanate method ${ }^{5}$ before 1984 and by the 2,4-dinitrophenyl hydrazine method thereafter. ${ }^{6}$ The results from parallel samples in a pilot experiment using the two methods showed no significant difference. Blood $\mathrm{ChE}$ activity was mea- sured by the modified method of Hestrin. ${ }^{7}$ The reference values for healthy women are 117.2 \pm 22.4 units. Cases of poisoning and suspected poisoning were diagnosed when the blood $\mathrm{ChE}$ activity was reduced to 50 and 70 units respectively.

All EEG tracings were assessed according to the following published criteria ${ }^{8}$ : an EEG was considered abnormal when it contained epileptiform activity waves, slow waves, or amplitude abnormalities. So far as this study is concerned, a mild abnormality of the EEG was defined as slow waves consisting of sporadic theta waves occurring on average no more than once every 10 seconds or amplitude reduction to $50 \%$ of the reference setting (pre-exposure). If the EEG changes were intermediate between normal and mild this was labelled marginal abnormality.

\section{Results}

MONITORING DATA FROM 1977 TO 1982

Table 1 shows the trend of declining air concentration in the workshop in recent years and declining incidence in cases of poisoning. There was no apparent change in the blood $\mathrm{ChE}$ activity for the workers exposed to dipterex over the same period. When the results from table 1 were arranged by quarter, the cases of poisoning and suspected poisoning seemed to be related to the season, as shown in table 2. Although the higher air concentrations were measured in the first and fourth quarters, the cases of poisoning were observed only in the second and third quarters and most cases of suspected poisoning were also observed in these two quarters. The incidence rates of poisoning plus suspected poisoning by quarter showed a statistically significant difference $\left(\chi^{2}=\right.$ 43.04, p < 0.001).

Table 3 presents the comparison of blood ChE values for subjects according to duration of continuous exposure. Despite the fact that longer term workers had higher historical air exposures, no significant differences in blood ChE activity were found in any of three categories.

Table 1 Concentration of dipterex in the workshop air compared with blood cholinesterase (ChE) and poisoning in workers (1977-82)

\begin{tabular}{|c|c|c|c|c|c|c|c|}
\hline \multirow[t]{2}{*}{ Years } & \multicolumn{3}{|c|}{ Air concentration $\left(\mathrm{mg} / \mathrm{m}^{3}\right)$} & \multicolumn{2}{|c|}{ End cycle* blood ChE values (unit) } & \multicolumn{2}{|c|}{ Poisoning } \\
\hline & $\begin{array}{l}\text { No of } \\
\text { samples }\end{array}$ & $M e a n \pm S D$ & Median & $\begin{array}{l}\text { No of workers } \\
\text { exposed }\end{array}$ & $M e a n \pm S D$ & No & $\%$ \\
\hline $\begin{array}{l}1977 \\
1978 \\
1979 \\
1980 \\
1981 \\
1982\end{array}$ & $\begin{array}{l}58 \\
58 \\
133 \\
104 \\
115 \\
137\end{array}$ & $\begin{array}{l}2.09 \pm 2.28 \\
3.30 \pm 3.24 \\
2.74 \pm 2.70 \\
2.13 \pm 2.70 \\
1.93 \pm 2.57 \\
0.95 \pm 1.37\end{array}$ & $\begin{array}{l}1 \cdot 18 \\
2.48 \\
2.40 \\
0.96 \\
0.92 \\
0.28\end{array}$ & $\begin{array}{r}110 \\
39 \\
47 \\
37 \\
36 \\
41\end{array}$ & $\begin{array}{l}89.8 \pm 18.5 \\
90.4 \pm 19.0 \\
98.0 \pm 23.9 \\
87.5 \pm 21.2 \\
74.4 \pm 19.0 \\
88.1 \pm 18.9\end{array}$ & $\begin{array}{l}2 \\
2 \\
6 \\
1 \\
1 \\
0\end{array}$ & $\begin{array}{r}1 \cdot 8 \\
5 \cdot 1 \\
12 \cdot 8 \\
2.7 \\
2 \cdot 8 \\
0.0\end{array}$ \\
\hline
\end{tabular}

*Concentrations determined at end of three month work cycle. 
Table 2 Incidence rates of poisoning in different calendar quarters (1977-82)

\begin{tabular}{|c|c|c|c|c|c|c|c|}
\hline \multirow[t]{2}{*}{ Quarters } & \multicolumn{3}{|c|}{ Air concentration $\left(\mathrm{mg} / \mathrm{m}^{3}\right)$} & \multicolumn{4}{|c|}{ No of cases of poisoning } \\
\hline & $\begin{array}{l}\text { No of } \\
\text { samples }\end{array}$ & $M e a n \pm S D$ & $\begin{array}{l}\text { \% Samples } \\
\text { exceeding } \\
M A C^{*}\end{array}$ & Confirmed & $\% \dagger$ & Suspected & $\% \dagger$ \\
\hline $\begin{array}{l}\text { Jan-Mar } \\
\text { Apr-Jun } \\
\text { Jul-Sep } \\
\text { Oct-Dec }\end{array}$ & $\begin{array}{l}124 \\
129 \\
193 \\
153\end{array}$ & $\begin{array}{l}2.52 \pm 2.82 \\
1.75 \pm 2.35 \\
1.71 \pm 2.28 \\
2.43 \pm 2.74\end{array}$ & $\begin{array}{l}58.9 \\
51 \cdot 2 \\
46 \cdot 1 \\
56.9\end{array}$ & $\begin{array}{l}0 \\
3 \\
9 \\
0\end{array}$ & $\begin{array}{l}0.0 \\
2.0 \\
5.4 \\
0.0\end{array}$ & $\begin{array}{r}12 \\
15 \\
45 \\
6\end{array}$ & $\begin{array}{r}11 \cdot 3 \\
10 \cdot 1 \\
27 \cdot 1 \\
5 \cdot 6\end{array}$ \\
\hline
\end{tabular}

*MAC (maximum allowable concentration) $=1 \mathrm{mg} / \mathrm{m}^{3}$.

†Percentage of total number of subjects working in this quarter in any year.

Table 3 Comparison of blood ChE values between continuous long term packers and intermittent cycle packers (1977-9)

\begin{tabular}{|c|c|c|c|c|}
\hline Packers & $\begin{array}{l}\text { Duration of exposure } \\
\text { (months) }\end{array}$ & $\begin{array}{l}\text { No of persons } \\
\text { examined }\end{array}$ & $\begin{array}{l}\text { Blood ChE values (unit) } \\
(\text { Mean } \pm S D)\end{array}$ & $p$ \\
\hline $\begin{array}{l}\text { Long term } \\
\text { Intermittent } \\
\text { Long term } \\
\text { Intermittent } \\
\text { Long term } \\
\text { Intermittent }\end{array}$ & $\begin{array}{l}7-12 \\
\leqslant 6 \\
13-18 \\
\leqslant 6 \\
19-24 \\
\leqslant 6\end{array}$ & $\begin{array}{l}37 \\
19 \\
58 \\
29 \\
47 \\
31\end{array}$ & $\begin{array}{r}89.0 \pm 17.0 \\
94.2 \pm 15.8 \\
103.3 \pm 16.4 \\
108.4 \pm 13.6 \\
97.2 \pm 23.4 \\
90.7 \pm 30.0\end{array}$ & $\begin{array}{l}>0.05 \\
>0.05 \\
>0.05\end{array}$ \\
\hline
\end{tabular}

AIR SAMPLING AND HEALTH SURVEILLANCE FOR WORKERS IN THE FIRST FOUR SEASONS During the study period the average air concentrations were near or below $1.0 \mathrm{mg} / \mathrm{m}^{3}$. The blood ChE activity of the study groups was consistently statistically significantly inhibited three months after employment as compared with their baseline (preexposure) (table 4). EEG examinations of packers who were seen both before and after exposure showed no significant increase in the percentage of total abnormalities (table 5).

Tables 6 and 7 show partial and multiple correlation coefficients between the results of air sampling and the health variables. The strongest correlations were found between air concentration and inhibition of blood $\mathrm{ChE}$ value and between inhibition of ChE activity and abnormality of EEG but none of the correlations was significant at the $5 \%$ level.
AIR MONITORING AND HEALTH SURVEILLANCE FOR THE FINAL SEASON

Table 8 presents the average air concentrations of $\subsetneq$ dipterex at the different work stations and the estimated eight hour time weighted average exposures for $\vec{\bullet}$ workers during the final two month cycle. It must be remembered that limited job rotation occurred during $\square$ this final exposure season. Table 8 also presents the estimated dermal contamination of packers at the different work stations. Both the average air concentrations and the estimated time weighted average concentrations were below the official MAC and near the recommended revision value. At these exposure $\underline{O}$ levels, blood ChE activity was mildly inhibited in most of the packers after exposure for one month and from mildly to moderately inhibited in all packers after exposure for two months (figure) $(F=26 \cdot 7, p<$ $0 \cdot 01)$.

Table 4 Mean and median air concentration and blood ChE values

\begin{tabular}{|c|c|c|c|c|c|c|c|c|}
\hline Quarters & $\begin{array}{l}\text { No of } \\
\text { samples }\end{array}$ & Mean $\pm S D$ & Median & $\begin{array}{l}\text { No of } \\
\text { persons } \\
\text { examined }\end{array}$ & $\begin{array}{l}\text { Blood ChE } \\
\text { pre-exposure } \\
(\text { Mean } \pm S D)\end{array}$ & $\begin{array}{l}\text { Blood ChE } \\
\text { post-exposure } \\
(\text { Mean } \pm S D)\end{array}$ & $\begin{array}{l}\% \\
\text { Reduction }\end{array}$ & $p^{*}$ \\
\hline $\begin{array}{l}\text { Jan-Mar } \\
\text { Apr-Jun } \\
\text { Jul-Sep } \\
\text { Oct-Dec }\end{array}$ & $\begin{array}{l}16 \\
20 \\
16 \\
16\end{array}$ & $\begin{array}{l}1.07 \pm 1.25 \\
0.58 \pm 0.78 \\
0.41 \pm 0.79 \\
1.30 \pm 1.50\end{array}$ & $\begin{array}{l}0.61 \\
0.63 \\
0.60 \\
0.60\end{array}$ & $\begin{array}{l}14 \\
16 \\
13 \\
11\end{array}$ & $\begin{array}{l}106.6 \pm 13.1 \\
117.9 \pm 7.1 \\
114.3 \pm 8.8 \\
119.6 \pm 16.4\end{array}$ & $\begin{array}{l}94.1 \pm 13.3 \\
90.5 \pm 22.9 \\
94.2 \pm 25.9 \\
89.1 \pm 16.1\end{array}$ & $\begin{array}{l}11 \cdot 7 \\
23 \cdot 2 \\
17 \cdot 6 \\
25 \cdot 5\end{array}$ & $\begin{array}{l}<0.05 \\
<0.01 \\
<0.05 \\
<0.01\end{array}$ \\
\hline
\end{tabular}

"Paired " $t$ " test for difference in pre-exposure and postexposure mean blood ChE value.

Table 5 Findings of EEG examination

\begin{tabular}{|c|c|c|c|c|c|c|c|}
\hline & \multirow{3}{*}{$\begin{array}{l}\text { No of subjects } \\
\text { examined }\end{array}$} & \multicolumn{6}{|c|}{ Abnormal cases } \\
\hline & & \multicolumn{2}{|c|}{ Marginal } & \multicolumn{2}{|c|}{ Mild } & \multicolumn{2}{|c|}{ Total } \\
\hline & & No & $\%$ & No & $\%$ & No & $\%$ \\
\hline $\begin{array}{l}\text { Pre-exposure } \\
\text { Postexposure }\end{array}$ & $\begin{array}{l}37 \\
37\end{array}$ & $\begin{array}{l}3 \\
6\end{array}$ & $\begin{array}{r}8 \cdot 1 \\
16 \cdot 2\end{array}$ & $\begin{array}{l}2 \\
3\end{array}$ & $\begin{array}{l}5 \cdot 4 \\
8 \cdot 1\end{array}$ & $\begin{array}{l}5 \\
9\end{array}$ & $\begin{array}{l}13 \cdot 5 \\
24 \cdot 3\end{array}$ \\
\hline
\end{tabular}


Table 6 Partial and multiple correlation coefficients* between inhibition of blood ChE and its independent variables

\begin{tabular}{ll}
\hline & Inhibition of blood ChE \\
\hline Duration of exposure & 0.013 \\
Air concentration & 0.230 \\
Multiple correlation coefficient & 0.245 \\
\hline
\end{tabular}

*None was significant at $\mathrm{p}<0.05$.

Table 7 Partial and multiple correlation coefficients* between abnormality of EEG and its independent variables

\begin{tabular}{ll}
\hline & Abnormality of EEG \\
\hline Duration of exposure & 0.060 \\
Air concentration & 0.249 \\
Multiple correlation coefficient & 0.26 \\
\hline
\end{tabular}

*None was significant at $\mathrm{p}<0.05$.

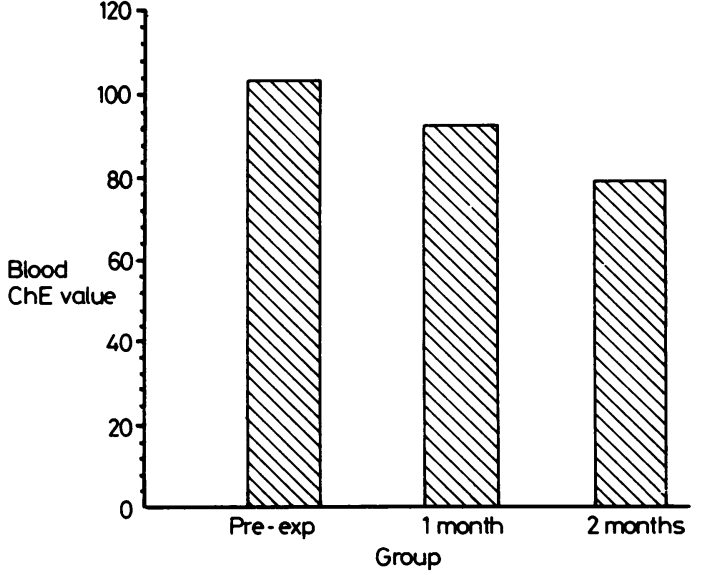

Change of blood ChE activity of 22 packers exposed to dipterex. $\mathbb{N}$ : mean $\pm S D$; pre-exposure: $102 \cdot 9 \pm 7 \cdot 2$; one month exposure: $92.4 \pm 14 \cdot 3$; two month exposure: $78 \cdot 8 \pm 10 \cdot 3$.

Table 8 Air and dermal concentrations and TWA estimates at different working sites (ug/cm ${ }^{2}$ )

\begin{tabular}{|c|c|c|c|c|c|c|c|c|}
\hline \multirow{3}{*}{$\begin{array}{l}\text { Working } \\
\text { stations }\end{array}$} & \multicolumn{4}{|l|}{ May } & \multicolumn{4}{|l|}{ June } \\
\hline & \multirow{2}{*}{$\begin{array}{l}\text { No of } \\
\text { samples }\end{array}$} & \multicolumn{2}{|c|}{ Air concentration $\left(\mathrm{mg} / \mathrm{m}^{3}\right)$} & \multirow{2}{*}{$\begin{array}{l}\text { Dermal } \\
\text { concentration }\end{array}$} & \multirow{2}{*}{$\begin{array}{l}\text { No of } \\
\text { samples }\end{array}$} & \multicolumn{2}{|c|}{ Air concentration $\left(\mathrm{mg} / \mathrm{m}^{3}\right)$} & \multirow{2}{*}{$\begin{array}{l}\text { Dermal } \\
\text { concentration }\end{array}$} \\
\hline & & $\bar{X} \pm S D$ & $T W A$ & & & $\bar{X} \pm S D$ & $T W A$ & \\
\hline $\begin{array}{l}\text { Bottle setting } \\
\text { Boxing } \\
\text { Bottle filling } \\
\text { Box removal } \\
\text { Final packing } \\
\text { Dinterex }\end{array}$ & $\begin{array}{l}8 \\
8 \\
8 \\
8 \\
4\end{array}$ & $\begin{array}{l}0.46 \pm 0.29 \\
0.30 \pm 0.24 \\
0.52 \pm 0.32 \\
0.30 \pm 0.24 \\
0.01 \pm 0.01\end{array}$ & $\begin{array}{l}0.38 \\
0.37 \\
0.21\end{array}$ & $\begin{array}{l}1.25 \pm 0.39 \\
2.92 \\
5.92 \pm 2.65 \\
1.54 \pm 0.71 \\
1.11 \pm 0.36\end{array}$ & $\begin{array}{l}8 \\
8 \\
8 \\
8 \\
4\end{array}$ & $\begin{array}{l}0.36 \pm 0.24 \\
0.57 \pm 0.33 \\
0.54 \pm 0.44 \\
0.57 \pm 0.33 \\
0.14 \pm 0.16\end{array}$ & $\begin{array}{l}0.43 \\
0.50 \\
0.27\end{array}$ & $\begin{array}{l}1.40 \pm 0.74 \\
2.87 \pm 1.55 \\
7.20 \pm 2.03 \\
1.60 \pm 1.01 \\
1.88 \pm 0.67\end{array}$ \\
\hline $\begin{array}{l}\text { Dipterex } \\
\text { transfer } \\
\text { Lounge* }\end{array}$ & $\begin{array}{l}3 \\
6\end{array}$ & $\begin{array}{l}0.96 \pm 0.69 \\
0.37 \pm 0.18\end{array}$ & $\begin{array}{l}0.64 \\
0.37\end{array}$ & $\begin{array}{l}1.18 \pm 0.28 \\
0.50\end{array}$ & $\begin{array}{l}3 \\
5\end{array}$ & $\begin{array}{l}0.84 \pm 0.30 \\
0.37 \pm 0.20\end{array}$ & $\begin{array}{l}0.60 \\
0.37\end{array}$ & $\begin{array}{l}0.97 \pm 0.25 \\
0.37\end{array}$ \\
\hline
\end{tabular}

*A worker labelled bottles in this room connected to main packaging area.

Table 9 Partial and multiple correlation coefficients between different variables

\begin{tabular}{lcc}
\hline & $\begin{array}{l}\text { Inhibition of blood ChE } \\
\text { at one month }\end{array}$ & $\begin{array}{c}\text { Inhibition of blood ChE } \\
\text { at two months }\end{array}$ \\
\hline Duration of exposure & -0.160 & -0.180 \\
Air concentration & 0.476 & 0.494 \\
Dermal contamination & 0.403 & 0.396 \\
Multiple correlation coefficient & $0.573^{*}$ & $0.599^{*}$ \\
\hline
\end{tabular}

p $<0.05$.

Table 9 shows the partial and multiple correlation coefficients between different variables for this final two month period. None of the partial correlation coefficients was statistically significant but the multiple correlation coefficients were consistently significant, indicating the likely importance of absorption from both the respiratory tract and from dermal contamination.

\section{Discussion}

Studying the main route of absorption of a chemical is an important aspect in the role of preventing an occupational hazard. In addition to chemical properties many other factors, such as the variation in working conditions at different workplaces, can influence absorption. In this study analysis using partial and multiple correlation coefficients suggested that both the time weighted average air concentrations and dermal contamination contributed positively to the inhibition of blood ChE activity $(r=0.573, p<0.05$; $r=0.599, p<0.05$ ). Furthermore, the evaluation of historical surveillance data showed that, whereas air concentrations in the first and fourth seasons were 
higher, cases of poisoning were observed only in the second and third seasons (the warmer seasons). This suggested that dermal absorption was the major route in the case of poisoning in the warmer seasons, when many factors would facilitate dermal absorption, such as a larger exposed surface area, higher dermal temperature, and increased sweating. Therefore, dermal contamination must be considered in the evaluation of exposure levels.

Determination of blood ChE activity has been regarded as an objective index for evaluating the health status of workers exposed to organophosphorous pesticides. It is also a measure that integrates exposure by different routes. If a pesticide has the potential for multiple routes of entry measuring air concentrations alone will almost always underestimate the real exposure concentrations. Therefore, quantifying the blood $\mathrm{ChE}$ activity of exposed workers can reflect the effective exposure levels regardless of route of entry. Using this approach, the present study showed that no significant differences in blood ChE activity were present between the long term and short term packers (table 3). Some local health authorities have suggested that, with continued exposure, blood ChE becomes refractory to further change. These data suggest that monitoring blood $\mathrm{ChE}$ is sufficiently sensitive for both long term and short term exposed workers.

There has also been some controversy concerning the practical value of the EEG in evaluating chronic toxic effects of organophosphorous pesticides on the nervous system ${ }^{49}$ (Beijing Chaoyang Hospital 1972, and Jiangshu Province Collaboration Committee, and Experimental Institute of Zhejiang People's Health, unpublished data, 1974). Some have shown excessive abnormalities of EEG in exposed workers, others have not. This difference might result from a variation in exposure concentrations, duration of exposure, and different diagnostic criteria. In the present study the workers primarily experienced intermittent chronic exposure (total duration of actual exposure varied from three months to ten years). When subjects were taken as their own control, no significant differences were found when comparing pre-exposure and postexposure EEG abnormality rates over a three month interval. Furthermore, there was no significant correlation between the inhibition of blood ChE activity and EEG changes. It seems that dipterex has no short term neurological effects detectable in intermittently exposed workers at these exposure concentrations. One thing worth mentioning, however, is that two of the three permanently employed packers showed abnormal EEGs. If work related these abnormalities may result from previous exposure to higher levels of dipterex, since slow recovery of EEG changes has been shown. ${ }^{4}$ Further EEG examination is still indicated to monitor long term exposed workers.

The findings of this study are not inconsistent with ? those of the earlier field study, ${ }^{4}$ which concluded that $\overrightarrow{\vec{B}}$ inhalation was the principal entrance route for dipterex. The different conclusions may be accounted for primarily by the higher air concentration in the previous report (several times greater than the MAC). In addition, the study was limited to the cold seasons when relatively little dermal exposure occurred. Fi- \& nally, the earlier study lacked as complete an evaluation of the way in which dermal contamination may contribute to measured health effects. Under the conditions reported here, with lower air concentrations and increased opportunity for dermal contamination, it is reasonable to believe that dermal absorption plays an important part in the depression of blood ChE activity.

Although the blood $\mathrm{ChE}$ effects reported here, no doubt, are the consequence of dipterex exposure, they do not alone indicate a toxic response ${ }^{10}$ but reflect a depletion in the body's reserve potential for organophosphate detoxification. ${ }^{11}$ Considering the fact that the inhibition of blood ChE here is partly attributed to dermal absorption, we conclude that the proposed reduction in MAC value $\left(0.5 \mathrm{mg} / \mathrm{m}^{3}\right)$ may only be regarded as relatively safe.

We thank Dr David H Wegman, director of the Department of Environmental and Occupational Health Sciences, School of Public Health, UCLA, for his critical review of this manuscript. We also thank our faculty member Dr Ruiwen Zhang for his work in design of the dermal contamination methods and Dr Juxiang Huang and Rejiou Pan from the Toxicological Laboratory, Shangai Pesticide Factory, for their help in the field study.

\section{Appendix}

METHOD FOR ESTIMATING DERMAL EXPOSURE

(1) Determine surface area (S) of subjects, pre-

dicted from weight and height.
(2) Determine total skin area (S1) to be sampled to obtain minimal measurable concentrations based on $\tilde{O}$ pilot study. In the present work setting $44 \mathrm{~cm}^{2}$ was a sufficient sample area.

(3) Distribute total sample area proportionally $N_{\omega}$ among exposed areas. In the present study hand, face, and neck were exposed areas. Based on the propor- $\theta$ tional distribution of these parts of the whole body surface area $(5 \%, 3 \%, 3 \%)$, areas samples on each $\stackrel{\mathcal{C}}{\rightarrow}$ part were $20,12,12 \mathrm{~cm}^{2}$, respectively.

(4) Sampling protocol:

(a) Use gauze dampened with distilled water to 
wipe each exposed area three times (area may be accurately sampled by placing a small plastic sheet with appropriate sized holes on skin surface).

(b) All gauze patches from a subject are placed in a container with $50 \mathrm{ml}$ distilled water for about one hour before measuring total concentration.

(c) Ten per cent $(5 \mathrm{ml})$ of solution are sampled for measurement of dipterex $\left(\mathbf{M}^{1}\right)$.

(5) Calculation to estimate dermal exposure:

(a) the average contamination ( $\bar{C})$ of sampled area:

$$
\widetilde{C}=\frac{\mathbf{M}^{1} \times 10}{\mathbf{S}^{1}}
$$

(b) total area contaminated (A):

$$
A=S(5 \%+3 \%+3 \%)
$$

(c) total amount of contamination of skin (M):

$$
\mathbf{M}=\mathbf{A} \times \overline{\mathbf{C}}
$$

(d) amount of pollutant per unit of total body surface area $(\mathrm{P})$ :

$$
P=\frac{M}{S}
$$

or:

$$
\begin{gathered}
P=\frac{A \times \bar{C}}{S} \\
=\frac{S(5 \%+3 \%+3 \%) \times \bar{C}}{S} \\
=(5 \%+3 \%+3 \%) \times \bar{C}
\end{gathered}
$$

Remarks:

(1) Only one container is needed even though several areas are sampled.

(2) If interest is only in the amount of pollutant per unit of body surface area prediction of the surface area is not necessary.

\section{References}

${ }^{1}$ Clinical effect of cholinesterase inhibition by OP compounds. Bull WHO 1971;44 \& suppl:289-307.

${ }^{2}$ Machemer L. Chronic toxicity of metrifonate. Acta Pharmacol Toxicol $1981 ; 49$ suppl:1-5(15-28).

${ }^{3}$ Shanghai Collaboration Committee on Control of Intoxication of Organophosphorous Insecticides. Dynamic observation of RBC ChE activity changes for workers exposed to organophosphorous insecticides. Health Research 1977;1:23-9. (In Chinese.)

${ }^{4} \mathrm{Lu}$ Y-P. Evaluation of the present MAC of dipterex in the air of workshop. Journal of Chinese Preventive Medicine 1983;17: 144-8. (In Chinese.)

${ }^{5}$ Institute of Health Research, Chinese Academy of Medical Science. Methods of measuring hazardous chemicals in the air. Peijing: People's Health Publish Bureau, 1974:425. (In Chinese.)

${ }^{6}$ Qie W. The determination of the concentration of dipterex in air. Health Research 1975;4:6. (In Chinese.)

${ }^{7}$ Shanxi Medical College. Occupational health and disease. Taiyuan: People's Health Publish Bureau, 1981:474-6. (In Chinese.)

${ }^{8}$ Department of Electrical Neurophysiology, Institute of Neurosurgery, Beijing. Clinical electroencephalogram. Beijing: I of $\mathbf{N}$, 1974:33. (In Chinese.)

${ }^{9}$ Dille JR, Smith PW. Central nervous system effects of chronic exposure to organophosphate insecticides. Aerospace Medicine 1964;35:474.

${ }^{10}$ Cavagna G. Clinical effects of exposure to DDVP (Vapona) insecticide in hospital wards. Arch Environ Health 1969;19:112-3.

${ }^{11}$ Hayes Al. Assessment of occupational exposure to organophosphates in pest control operators. Am Ind Hyg Assoc J 1980;41:568-75. 